\title{
УДК 656.222.6
}

\section{О. О. МАЗУРЕНКО ${ }^{1}$, А. В. КУДРЯШОВ ${ }^{2} *$}

$1^{*}$ Каф. «Станції та вузли», Дніпропетровський національний університет залізничного транспорту імені академіка В. Лазаряна, вул. Лазаряна, 2, 49010, м. Дніпро, Україна, тел. +38 (056) 373-15-12, ел. пошта sash_ok_ua@mail.ru, ORCID 0000-0001-5591-1790

$2^{*}$ Каф. «Станції та вузли», Дніпропетровський національний університет залізничного транспорту імені академіка В. Лазаряна, вул. Лазаряна, 2, 49010, м. Дніпро, Україна, тел. +38 (056) 373-15-12, ел. пошта andkyd@ mail.ru, ORCID 0000-0002-5965-3378

\section{ПЕРСПЕКТИВИ ПОДАЛЬШОГО РОЗВИТКУ МІЖНАРОДНИХ ТРАНСПОРТНИХ КОРИДОРІВ УКРАЇНИ}

В статті виконано пошук шляхів підвищення міждержавного транзиту та перспективи подальшого розвитку міжнародних транспортних коридорів, які проходять територією України. Розглянуто чинники, які визначають втрати транзитних вантажопотоків та потребують вирішення на загальнодержавному рівні та корінного реформування транспортної сфери в цілому. Наведено потенційні можливості для залучення додаткових транзитних потоків через свою територію за умови впровадження нових форм співробітництва 3 міжнародними партнерами та модернізації власної транзитної транспортної інфраструктури. Також в статті обговорюється проблема введення швидкісного руху в міжнародному сполученні на залізницях, що потребує комплексного, гармонійного розвитку всіх компонентів. Наведено доцільні етапи підвищення швидкості руху поїздів. Доведено, що підвищення міждержавного транзиту через українську територію створить умови підвищення якості та ефективності зовнішньоекономічних зв'язків країни, сприяє ефективному використанню резервів перевізних можливостей національних транспортних систем, стимулює їхнє відтворення та удосконалення. На підставі аналізу ряду наукових праць сформульовані принципи, на яких повинен базуватися розвиток мережі міжнародних транспортних коридорів по території України.

Ключові слова: міжнародні транспортні коридори, міждержавний транзит, підвищення швидкості руху, транспорт.

\section{Введення}

Україна має розгалужену транспортну систему. Саме транспорт є однією з важливих галузей народного господарства, ефективне функціонування якого $є$ необхідною умовою розширення торгово-економічних відносин, забезпечення потреб населення й суспільного виробництва в перевезеннях i, як наслідок, гарантія стабільного розвитку економіки. У цьому зв'язку рівень розвитку транспортної системи держави $€$ одним 3 найважливіших ознак його технологічного прогресу та цивілізованості [1].

Система міжнародних транспортних коридорів (МТК) сьогодні активно розвивається в усьому світі, насамперед у Європі, що багато в чому пов'язано з глобалізацією світової економіки та переміщенням промислових підприємств з Свропи до Азії та Африки. Україна має безпосередні транспортні контакти із країнами Східної та Західної Європи, широкий вихід до Чорного моря. Вона займає важливе місце в західних комунікаціях Росії й центральноазіатських країн. По багатьох ключових напрямках перевезень іiі комунікації не мають альтернативи [2].

Міждержавний транзит через українську те- риторію - це значний національний ресурс, який на сьогодні використовується не повною мірою [3]. Пошуки шляхів підвищення його використання являє собою важливе, у науковому і практичному відношенні, завдання науковців і практиків, що зумовлює актуальність обраної теми дослідження. Інтеграція України через міжнародні транспортні коридори в міжнародне співтовариство дасть нашій країні та ії регіонам підгрунтя динамічного розвитку економіки, створить умови підвищення якості та ефективності зовнішньоекономічних зв'язків країни, посилить ефективність використання транзитного потенціалу, поліпшить соціальноекономічний стан в регіонах [4].

\section{Основна частина}

Чинники, які визначають втрати транзитних вантажопотоків, можна розділити на дві групи: зовнішні та внутрішні [1]. Більшість із внутрішніх проблем функціонування транспортного комплексу мають системний характер і потребують вирішення на загальнодержавному рівні та корінного реформування транспортної сфери в цілому.

Зовнішні чинники: 
- зміна кон'юнктури міжнародного ринку транспортних перевезень (зростання обсягів комбінованих перевезень, зростання вимог до швидкості та якості транспортних послуг та перевезень, зміни в структурі транзитних вантажів на користь контейнерів, тарно-штучних вантажів, зменшення транзиту металу, наливних вантажів і т.д.);

- зростання міжнародної конкуренції на державному рівні за додаткові транзитні потоки. Як наслідок, переорієнтація транзиту з портів України на порти сусідніх країн;

- різні темпи трансформації та інтеграції національних транспортних систем у міжнародну транспортну систему, зокрема прискорений розвиток транспортної інфраструктури конкуруючих 3 нами країн.

Внутрішні чинники, які мають технікоекономічний, політичний та правовий характер:

- відставання в темпах розбудови української частини системи міжнародних транспортних коридорів;

- низька якість внутрішньої транспортної мережі, обмеженість швидкості транзитних перевезень, технічно застарілий рухомий склад;

- низький рівень розвитку інфраструктури державного кордону, низька пропускна спроможність прикордонних пунктів пропуску та відносно висока вартість послуг, що надаються при перетині кордону, складна та тривала процедура проходження кордону, простої на кордоні;

- політична та економічна нестабільність, часті зміни в законодавчому та правовому полі щодо здійснення транспортних перевезень та процедури перетину кордонів, неузгодженість національних законодавчих актів 3 відповідними нормами в європейських країнах;

- недостатньо гнучка тарифна політика, яка не завжди враховує зміни в тарифній політиці конкуруючих 3 нами країн та не сприяє забезпеченню конкурентоздатності перевезень по території України в порівнянні з іншими країнами, наявність місцевих зборів, необхідність внесення фінансової застави й т.д.

Та попри перелічені проблеми Україна має потенційні можливості для залучення додаткових транзитних потоків через свою територію за умови впровадження нових форм співробітництва 3 міжнародними партнерами та модернізації власної транзитної транспортної інфраструктури та створення сприятливих умов для переміщення транзиту територією країни [1].

Розвиток транспортних коридорів в Україні дозволить ефективно використати вдале географічне розташування нашої країни на карті Європи, що, у свою чергу, буде сприяти ство- ренню нових робочих місць; значно збільшиться кількість замовлень українським підприємствам, а головне, це дозволить підняти рівень інвестиційної привабливості інфраструктури, що розвивається, забезпечить статус України як транзитної держави, сприятиме інтеграції національної транспортної системи в міжнародну транспортну систему та реалізації національних стратегічних інтересів.

Транзит є каталізатором розвитку широкого спектра супутніх послуг із заправлення транспортних засобів паливом, організації торгівлі й харчування, ремонту транспортних засобів та їх сервісного обслуговування [5]. Він стимулює розвиток власного транспортного машинобудування, сприяє ефективному використанню резервів перевізних можливостей національних транспортних систем, стимулює їхнє відтворення та удосконалення. Тому транзит варто розглядати не тільки як частину бізнесу, що додає свій внесок у ВВП, але і як важливий елемент міжнародного позиціонування країни.

Пошук вільних коштів на оновлення залізничних потужностей буде йти значно ефективніше, якщо створити конкурентне середовище у цій галузі [6]. Тобто напрямком діяльності держави має бути поступове скасування державної підтримки та створення ринкових умов. Кроком у цьому напряму була ліквідація монополії у діяльності залізниці.

Проблема визначення транзитного потенціалу України в системі міжнародних транспортно-комунікаційних зв'язків об'єктивно виходить за межі власних інтересів України у зв'язку з їі тяжінням до географічного центру Свропи [7]. Уже лише ця обставина може визначити пріоритети розвитку країни у напрямі більш тісної інтеграції 3 країнами Європейського Союзу та іншими міжнародними інституціями.

Швидкість перевезень - головна мета транспортної політики, яка успішно реалізується в країнах Західної Європи [8]. У багатьох європейських країнах проводиться посилена робота 3 модернізації залізничних ліній. Із загального полігону швидкісних напрямків (43 249 км), визначених Програмою [9], до 2005 р. на 13,1\% повинна була бути забезпечена швидкість пасажирських поїздів 160 км/год і вище.

Актуальність проблеми введення швидкісного руху в міжнародному сполученні на залізницях України зросла після розробки Концепції розвитку транспорту України на 1997-2010 р. [10] і прийняття Кабінетом Міністрів України Програми створення та функціонування національної мережі міжнародних транспортних коридорів в Україні [11]. У цих документах пе- 
редбачається технічна модернізація залізничних коридорів, а також підвищення швидкості руху поїздів на існуючих лініях міжнародного значення і виконання комплексу підготовчих робіт для забезпечення розвитку високошвидкісного руху в Україні.

Підвищення швидкості руху поїздів - це складна проблема, яка потребує комплексного, гармонійного розвитку всіх компонентів: вагонного і локомотивного парку, колійної інфраструктури, систем централізації, автоблокування, енергопостачання - i, відповідно, великих капіталовкладень [8].

Враховуючи вищевикладене, доцільно підвищення швидкості руху поїздів розділити на три етапи:

І етап - реабілітація колійної інфраструктури, приведення іiі у відповідність до міжнародних стандартів (капітальний, середній, комплексно-оздоровчий ремонт колії, заміна рейок, шпал, стрілочних переводів);

II етап - модернізація вантажного вагонного парку, обладнання його новими візками, розрахованими на швидкість до 120 км/год; модернізація засобів СЦБ та енергопостачання;

III етап - розділення пасажирського та вантажного руху, досягнення швидкості вантажних поїздів 120 км/год і більше.

На останньому етапі повинні бути ліквідовані всі перетинання залізничних колій 3 автошляхами на одному рівні, здійснена заміна їх шляхопроводами та частково перебудовані криві ділянки колій. 3 переходом на локомотиви нового покоління потребує оновлення локомотивний парк. Щодо ширини колії, то доцільно виглядають обидва варіанти - покращення системи перевантаження вагонів на кордоні та прокладання колії європейської ширини по стратегічно найважливіших напрямках, особливо в напрямку морських портів. Це, за прогнозами консалтингових фірм, програма віддаленої перспективи.

Реалізація запропонованих етапів підвищення швидкості руху поїздів потребує значних фінансових витрат. Укрзалізниця та Міністерство транспорту України таких коштів виділити не можуть, отже необхідно активно залучати інвесторів. Найбільш ймовірним інвестором є Китай. Його програма побудови нового Шовкового шляху не виключає участі України в транзиті вантажів до Свропи [12]. Перші кроки до залучення інвестицій з Китаю вже зроблено: у 2016 році підписано меморандум про співробітництво в інвестиційній, торговій та транспортній сферах, зокрема щодо роз- витку залізничних перевезень транзитних вантажів [13]. В той же час багато компаній з міжнародним капіталом вже інвестують власні кошти в розвиток залізничної інфраструктури [14].

\section{Висновки}

Організація перевезень в межах міжнародних транспортних коридорах залежить значною мірою від успішного вирішення проблеми постійної взаємодії. Робота таких складних об'єктів інфраструктури міжнародних транспортних коридорів в обов'язковому порядку має грунтуватися на повсюдному використанні можливостей інформаційних систем забезпечення МТК та стандартизованих документів змішаних перевезень пасажирів і вантажів, на єдиному, погодженому з усіма країнами-учасницями транспортному законодавстві.

Таким чином, пріоритетним для Укрзалізниці є розвиток мережі міжнародних транспортних коридорів по території України, який базується на таких принципах:

- модернізація інфраструктури;

- розділення пасажирських та вантажних перевезень;

- розвиток комбінованих і контрейлерних перевезень;

- застосування єдиних тарифів;

- організація швидкісного руху для просування транзитних вантажопотоків у міжнародному сполученні;

- удосконалення взаємодії різних видів транспорту в транспортних вузлах, розвиток інтермодальних систем міжнародних перевезень;

- створення єдиного інформаційного поля для всіх учасників перевізного процесу.

\section{БИБЛИОГРАФИЧЕСКИЙ СПИСОК}

1. Джулай, С. В. Одеський національний політехнічний університет Транзитний потенціал України: сучасний стан та проблеми використання [Електрон. ресурс]/ С. В. Джулай, С. С. Шаповал - Режим доступу: http://www.rusnauka.com/21_NIEK_2007/ Economics/24101.doc.htm

2. Позднякова, Л. А. Международные транспортные коридоры и особенность их формирования в Украине / Л. А. Позднякова // Вісник економіки транспорту і промисловості : Зб. наук. праць. - 2004. № $7 .-$ C. 4 .

3. Колесников, А. Перспективы для транзита / А. Колесников // Порты Украины. - 2007. - № 5. - С. 17-19.

4. Козак, В. В. Интенсификация международных железнодорожных перевозок / В .В. Козак // Залізн. трансп. України. - 2007. - № 2. - С. 3-4.

5. Альтернативи транспортної складової [Електронний ресурс]. - Режим доступу: http://bo0k.net 
/index.php?bid=3190\&chapter $=1 \& \mathrm{p}=$ achapter

6. Транспортна галузь України, проблеми і перспективи [Електронний ресурс]. - Режим доступу: http://www.refine.org.ua/pageid-4004-3.html

7. Транзитний потенціал України і його значення в розвитку економіки держави [Електронний ресурс]. - Режим доступу: http://pidruchniki.com/ 1422090638858/rps/tranzitniy_potentsial_ukrayini_yog o_znachennya_rozvitku_ekonomiki_derzhavi

8. Кірпа, Г. М. Інтеграція залізничного транспорту України у європейську транспортну систему : Монографія / Г. М. Кірпа. - 2-ге вид, перероб. і доп. - Дніпропетровськк: Ви-во Дні-го нац. ун-ту залізн. трансп. ім акад. В. Лазаряна, 2004. - 247 с.

9. О результатах разработок предложений по созданию скоростных и высокоскоростных железнодорожных линий в странах-членах ОСЖД // Бюллетень ОСЖД. - 2000. - № 3. - С. 9 - 13.

10.Концепция развития транспорта Украины на 1997-2010 гг. / Министерство транспорта Украины № 2 / 21-3-1428 от 14.11.1997. - К., 1997. - 25 с.
11.Програма створення та функціонування національної мережі міжнародних транспортних коридорів в Україні // Урядовий кур'єр. Орієнтир. 09.04.1998. - С. 7-16.

12.Китай зазывает в новый «Шелковый путь» [Электронный ресурс]. - Режим доступу: http://forbes.net.ua/news/1419357-kitaj-zazyvaet-vnovyj-shelkovyj-put

13.Китай пригласил Украину в Экономический пояс Шелкового пути [Электронный ресурс]. - Peжим доступу: http://ports.com.ua/news/kitay-priglasilukrainu-v-ekonomicheskiy-poyas-shelkovogo-puti

14.ТИС, «Бориваж» и ОЖД открыли вторую магистральную колею возле порта «Южный» [Электронный ресурс]. - Режим доступу: http://interfax.com.ua/news/general/302055.html

Стаття рекомендована до публікації д.т.н., проф. Герою Б. В. (Україна)

Надійшла в редколегію 08.11.2016.

Прийнята до друку 12.11.2016.

\section{А. А. МАЗУРЕНКО, А. В. КУДРЯШОВ}

\section{ПЕРСПЕКТИВЫ ДАЛЬНЕЙШЕГО РАЗВИТИЯ МЕЖДУНАРОДНЫХ ТРАНСПОРТНЫХ КОРИДОРОВ УКРАИНЫ}

В статье выполнен поиск путей повышения межгосударственного транзита и перспективы дальнейшего развития международных транспортных коридоров, которые проходят через территорию Украины. Рассмотрены факторы, которые определяют потери транзитных грузопотоков и требуют решения на общегосударственном уровне и коренного реформирования транспортной сферы в целом. Приведены потенциальные возможности для привлечения дополнительных транзитных потоков через свою территорию при условии внедрения новых форм сотрудничества с международными партнерами и модернизации собственной транзитной транспортной инфраструктуры. Также в статье обсуждается проблема введения скоростного движения в международном сообщении на железных дорогах, что требует комплексного, гармоничного развития всех компонентов. Приведены целесообразные этапы повышения скорости движения поездов. Доказано, что повышение межгосударственного транзита через украинскую территорию создаст условия для повышения качества и эффективности внешнеэкономических связей страны, способствует эффективному использованию резервов перевозочных возможностей национальных транспортных систем, стимулирует их восстановление и совершенствование. На основании анализа ряда научных трудов сформулированы принципы, на которых должно базироваться развитие сети международных транспортных коридоров на территории Украины.

Ключевые слова: международные транспортные коридоры, межгосударственный транзит, повышение скорости движения, транспорт.

\section{A. MAZURENKO, A. KUDRYASHOV}

\section{PERSPECTIVES OF FURTHER DEVELOPMENT OF INTERNATIONAL TRANSPORT CORRIDORS OF UKRAINE}

The article describes ways to enhance Intercountry transit and the prospects for further development of international transportation corridors, which extend through territory of Ukraine. Considered factors that determine the loss of transit cargo flows and demand the decision at the national level and fundamental reform of the transport sector as a whole. Presents potential opportunities for attracting additional transit flows through its territory subject to the implementation of new forms of cooperation with international partners and modernize its transit of the transport infrastructure. The article also referred to the railways issue introduction of high-speed movement in the international traffic, which requires an integrated and harmonious development of all the components. Presents expedient steps increase the speed of trains. It is proved, the elevated of Intercountry transit through Ukrainian territory will create conditions for improving the quality and efficiency of foreign economic relations of the country, promotes the effective use of reserves of transport capacity of national transport systems, stimulates recovery and improvement. Based on the analysis of a number of scientific papers formulates the principles on which should be based the development of international transport corridors on the territory of Ukraine.

Keywords: international transport corridors, Intercountry transit, increase the speed of trains, transport. 